\title{
Fundamento do direito internacional publico
}

\author{
SUMMARIO
}

$\$$ I." Base scientifica do direito em geral.

$\S 2^{\circ}$ Applicação da sua doutrina ao direito internacional publico.

$\$ 30^{\circ}$ "Consensus entre a evolução social e a juridica.

\section{$\S 10^{\circ}$}

\section{Base scientifica do direito em geral}

1. Primeira lei sociologica

O fundamento do direito internacional publico é a necessidade.

No paragrapho 110 dos meus Ensaios de Philosophia do Direito, pags. $624 \mathrm{e}$

No $\S 110$ dos meus Ensaios de Philosophia do Direito, pags. 624 e seguintes, encontram-se algumas considerações sobre as duas leis sociologicas fundamentaes, que servem de base scientifica ao direito em geral. Eil-as em resumo. A observação dos phenomenos da vida individual e social, em todos os pontos do espaço e do tempo, leva-nos a induzir, isto é, a, partindo do particular, chegar a esta verdade geral:o homem só vive e desenvolve-se na sociedade; esta é um meio necessario a elle, assim como é tambem a certos animaes. Os animaes gregarios só vivem e se desenvolvem na sociedade instinctiva por elles organizadla natural e necessariamente. A observação da vida 
individual humana dá-nos o conhecimento da natureza do homem e de seus attributos physicos e psychicos, revelando-se as leis reguladoras dos phenomenos de seu nascimento, crescimento, desenvolvimento e morte. E o conhecimento destas leis ou das relações constantes e uniformes que ligam esses phenomenos da vida humana, em sua dupla iace, physica e psychica, comprova o nosso asserto, porquanto, é do conhecimento da natureza humana que deduzimos, como natural consequencia, a necessidade da vida em sociedade.

Ahi está a primeira lei sociologica, expressão de uma necessidade incoercivel sentida pelo individuo.

\section{SEgUNDA LEI SOCIOLOGICA}

A observação dos phenomenos que se desdobram nas sociedades, quer de animaes, quer de homens, levanos, pela inducção, a esta outra generalização: a sociedade só é possivel, restringindo cada uma de suas unidades a sua actividade. Tão necessaria é esta restricção da actividade, que o proprio instincto a impõe aos animaes. As abelhas, os castores e as formigas vivem em sociedade, porque cada um dos membros da collectividade se mantém dentro de uma certa esphera de actividade, e respeita a da actividade dos outros consociados. A mesma necessidade, ineluctavel e evidente, de restringir a actividade individual, é imposta ao homem, que, capaz de raciocinar $\epsilon$ generalizar, comprehende essas duas verdades fundamentaes e, tendo a vontade impellida por sentimentos e ideias, é levado a fazer o que reconhece necessario á sua conservação e desenvolvimento.

Eis ahi a segunda lei sociologica fundamental.

Estas duas leis constituem a base scientifica do direito em geral.

Todo o conjuncto das normas juridicas, normae agendi, não passa de um systema de restricções impostas pela necessidade dá vida em commum ao campo de actividade de cada unidade social e, portanto, sob 
outra face, um systema parallelo de faculdades, facultates agendi, em que se declara o que a cada individuo é licito fazer, ou deixar de fazer.

\section{BASE SCIENTIFICA DO DIREITO}

Todas as instituições juridicas são calcadas sobre o principio da restricção de actividade individual, condição imprescindivel da vida social.

No direito das coisas, um dos capitulos do direito civil, o legislador estabelece uma série de restricções á actividade de cada unidade social, na acquisição, uso e goso das coisas materiaes de que necessita o individuo para subsistir e desenvolver-se.

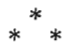

No direito das obrigações, outro capitulo do direito civil ou antes do direito privado, o legislador estabelece uma série de restricções á actividade de cada unidade social, na formação, execução e extincção dos contractos, cuja funcção é satisfazer a necessidade incessantemente crescente das permutas de coisas e de serviços.

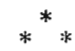

No direito da familia, ainda se nos apresenta uma série de restricções á actividade individual, com o mesmo cunho de necessidade, constituindo condição sine qua non da vida social.

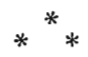

No direito de successão, o mesmo se nos depara. Por toda a parte as instituições juridicas se revelam ao observador com a missão de traçar e manter uma linha divisoria entre as unidades sociaes, para que possa cada uma se conservar e desenvolver, sem im- 
pedir a conservação e desenvolvimento das demais que com ella coexistem.

Isto posto, temos que, sendo o homem um ser essencialmente social, necessariamente impellido por sua natureza á vida em sociedade, é para elle de necessidade ineluctavel a limitação da actividade individual. Sem isso, os homens não poderiam coexistir na sociedade.

Essa limitação da actividade é, pois, uma condição primordial de vida e desenvolvimento para a sociedade e, pois, para o individuo tambem. E' uma necessidade para o individuo e para a collectividade. Para que a sociedade se conserve e desenvolva, é imprescindivel que cada individuo e cada uma das entidarles collectivas, que se constituem no seio da sociedade, tenha uma esphera de acção, dentro da qual realize as suas condições de vida e desenvolvimento, sem impedir os consociados de, por seu turno, se conservarem e desenvolverem.

Ahi está a base scientifica do direito, o seu principio fundamental assente na necessidade, aliás dupla, pois é sentida pela sociedade e pelos individuos.

$$
\S 2 .^{\circ}
$$

\section{Spplieacão da respectiva doutrina ao direito intermacional publico}

$O$ que vem de ser exposto tem perfeita applicação ao direito internacional publico, o que, aliás, é de ver, pois constitue principio commum a todo o direito, qualquer que seja o departamento do saber juridico.

Substitua-se a palavra individuo ou unidade social pela palavra estado, e se dê, á palavra sociedade, o sentido de associação ou communhão dos estados, conservando-se tudo mais.

Com esta pequena modificação, o expendido no referido $\S 110$ de meus Ensaios será uma demonstração satisfactoria de que a necessidade é o fundamento do direito internacional publico. Com effeito, o estado, como 
o individuo, é fatalmente impellido á vida social. A communhão internacional dos estados, como a sociedade dos individuos no estado, não póde subsistir e desenvolver-se, sem aquella condição primordial da limitação da actividade de cada unidade social, isto é, no caso, de cada estado. A série das limitações indispensaveis á conservação e desenvolvimento da sociedade dos estados, constituindo sob um aspecto um systema de faculdades e, sob outro aspecto um systema de normas, eis o directo internacional publico. Assenta, pois, ineluctavelmente, nessa necèssidade emergente da coexistencia dos estados na communhão internacional.

$E$ note-se que não é novidade este ensinamento que põe o fundamento do direito na necessidade, porquanto, já Modestino dizia:- "Omne jus aut necessitas fecit, aut consensus constituit, aut firmavit consuetudo».

$\mathrm{Si}$ considerarmos o consensus e a consuetudo como expressões, que são, da necessitas, teremos o jurisconsulto romano dando correctamente a necessidade como fundamento do direito. E' o que faz hoje a philosophia juridica, inspirada pelos ensinamentos da nova corrente da mentalidade humana.

\section{$\S 3 .^{\circ}$}

\section{Consensus necessario entre a evoluęão social e a juridica}

f. UNIVERSALIZAÇÃo SOCIAL

Não devo fechar esta succinta exposição da these, sem repetir uma observação muito fecunda, e é que a communhão dos estados é a ultima fórma assumida pela sociabilidade humana. A escala evolutiva é esta:

a) grupo patriarchal,

b) cidade classica,

c) estado e

d) sociedade mundial.

2. UnIVERSALIZAÇÃo JURIDICA

$O$ direito acompanha o homem nesta escala ascendente, modificando-se pari-passu afim de adaptar-se as 
novas condições e satisfazer as novas necessidades dellas emergentes.

Todas as manifestações da actividade de um povo se correspondem proporcionadamente. Influem-se reciprocamente, adaptam-se umas ás outras e equilibram-se, constituindo um todo organico e harmonico.

Assim, as normas juridicas de um povo prendem-se ás condições da vida individual e social desse povo, formando consensus com todas as diversas manifestações de sua actividade, conforme exponho no $\S 4 .^{\circ}$, de meus referidos Ensaios de Philosophia do direito, sob a epigraphe - do consensus dos phenomenos. Este conceito, que é uma conquista fertilissima do pensamento moderno, e de perfeito accôrdo com a realidarle objectiva da vida humana em todas as suas manifestações, deixa bem patente que o direito internacional publico (bem como o privado) não constitue um departamento isolado do saber juridico anterior. Pelo contrario, é o mesmo direito preexistente, que assume agora uma feição nova, afim de adaptar-se á fórma suprema e ultima da sociabilidade humana - a sociedade dos estados, e satisfazer as novas necessidades emergentes da transformação das condições da vida individual e social nessa nova e vastissima esphera.

\section{A NECESSIDADE É O FUNDAMENTO DO DIREITO DE HONTEM E DE HOJE}

$E$ assim sendo, a necessidade, fundamento do direito preexistente, é tambem o fundamento do direito novo.

Aos cultores do direito tambem se impõe a verdade scientifica, segundo a qual, o presente é filho do passado ou é este mesmo passado transformado e adaptado ás condições do momento historico actual. 